\title{
Effect of Organo-mineral Fertilizer on Tomato Fruit Production and Incidence of Blossom-end Rot under Salinity
}

\author{
Keiko Kataoka*, Kazuya Sugimoto, Hiroaki Ohashi and Hisashi Yamada \\ Graduate School of Agricultural Science, Ehime University, Matsuyama 790-8566, Japan
}

Tomato plants were grown with a drip irrigation system to evaluate the effects of a novel organo-mineral fertilizer [2:10:1 (w/w/w) mixture of calcium sulphate, ground rice bran, and humic acid] (OMF), which can mitigate salinity stress, on plant growth, fruit yield, and the incidence of blossom-end rot (BER) under salinity stress. Salinity stress was applied by drip irrigation with $50 \mathrm{mM}$ of $\mathrm{NaCl}$. Plant growth with OMF was lower than that with chemical fertilizer (CF). Higher levels of $K$ and $P$ were obtained in the leaves from plants grown with OMF. OMF inhibited $\mathrm{Na}$ accumulation and proline increase in the leaves and was considered to alleviate salinity stress. Salinity treatment caused a decrease in fruit weight and an increase in ascorbic acid, sucrose, glucose, fructose, and glutamic acid. Tomato plants grown with OMF had smaller fruit than with CF without salinity, but the incidence of BER under salinity was reduced by OMF. The water soluble Ca content of the distal half of young tomato fruit was significantly decreased with salinity treatment. The incidence of BER under salinity was significantly lower in OMF than in CF, but there was no difference in the concentration of every form of Ca between CF-salinity and OMF-salinity treatments. The reduction in BER incidence with OMF treatment could not be explained by the differences in Ca concentration. The mechanism of the reduction in BER with OMF was not clear, so further studies are necessary.

Key Words: abiotic stress, calcium concentration.

\section{Introduction}

In Japan, consumers desire fresh tomatoes with a high sugar content, which they regard as high quality. One of the ways to increase the sugar content of tomato fruit is to grow them under salinity stress (Saito et al., 2006, 2008; Zushi et al., 2005), and there are some famous tomato brand production localities in the Japanese market using salinity stress. However, salinity stress is accompanied by yield loss caused by a reduction in fruit weight and a higher incidence of physiological disorders such as blossom-end rot (BER).

There are many reports concerning BER, and the cause is considered to be Ca deficiency in the fruit, especially the distal part (de Freitas et al., 2011; Ho and White, 2005; Taylor and Locascio, 2004; Terabayashi et al., 1988; Yoshida et al., 2013, 2014). Ca is considered to play an important role in maintaining the integrity of plant cells (Ho and White, 2005) and exists in variable chemical forms. $\mathrm{NaCl}$-soluble $\mathrm{Ca}$ content has a

Received; July 28, 2016. Accepted; October 25, 2016.

First Published Online in J-STAGE on December 3, 2016.

* Corresponding author (E-mail: kataoka.keiko.mf@ehime-u.ac.jp). negative relationship with BER incidence (Terabayashi et al., 1988) and a decrease in water-soluble $\mathrm{Ca}$, which is a physiologically available form, is thought to be a major cause of BER incidence (Yoshida et al., 2014).

Meanwhile, soil salinization has become a serious global problem. Salinity is accountable for decreasing crop productivity in many areas and is one of the important problems that must be overcome. Rady (2012) showed that treating reclaimed saline soil $(\mathrm{EC}=$ $8.9 \mathrm{dS} \cdot \mathrm{m}^{-1}$ ) with a novel organo-mineral fertilizer (OMF) [2:10:1 (w/w/w) mixture of calcium sulphate, ground rice bran, and humic acid] increased the growth and fruit yield of tomato plants. Therefore, this OMF may be able to reduce yield loss in a high-quality tomato production system with salinity. Additionally, organic compounds are prospective nutrients sources for crop yield increases without soil health decline and off-site pollution (Paungfoo-Lonhienne et al., 2012).

In this study, we examined the effect of OMF on growth, fruit quality, and BER incidence under salinity and the relationship between the $\mathrm{Ca}$ concentration in fractions of the distal part of young fruits and the BER incidence. 


\section{Materials and Methods}

Exp. 1. Effects of OMF and salinity on plant growth and mineral absorption

Seeds of the tomato 'House Momotaro' were sown in seed trays with nursery soil on 19 February 2013 (summer cropping) and 27 August 2013 (winter cropping) in a growth chamber at $28 / 18^{\circ} \mathrm{C}, 17 \mathrm{~h}$ of day length, and a photosynthetic photon flux density of approximately $100 \mu \mathrm{mol} \cdot \mathrm{m}^{-2} \cdot \mathrm{s}^{-1}$. Two weeks later, the seed trays were moved to a greenhouse without heating. At 24 and 25 days after sowing, each seedling was transplanted to a plastic pot (diameter of $9 \mathrm{~cm}$ ) containing a decomposed granite soil-perlite mixture $(3: 1, \mathrm{v} / \mathrm{v})$ in a greenhouse and was fertilized with a nutrient solution (a half strength of the A-type recipe of Otsuka House Solution; Otsuka Chemical Co., Ltd., Japan) every 2 days. On 10 April 2013 and 11 October 2013, when the first truss appeared, each seedling was transplanted to a $5000^{-1}$-a Wagner pot containing the same medium mentioned above. Plants were placed in two rows $(20$ pots in $5 \mathrm{~m}$ long rows, $1.0 \mathrm{~m}$ between rows) in a greenhouse $(9.0 \times$ $17.5 \mathrm{~m})$. In winter cropping, the rows of plants were covered with a plastic tunnel and heated with an oil heater to maintain a minimum temperature of $15^{\circ} \mathrm{C}$ from 10 December [60 days after transplanting (DAT)]. Plants were irrigated with well-water through a drip irrigation system at appropriate times corresponding to growth. Every truss was sprayed with $15 \mathrm{mg} \cdot \mathrm{L}^{-1}$ of a 4chlorophenoxy acetic acid (4-CPA; Nissan Chem. Ind. Ltd., Japan) solution. The number of fruits per truss was adjusted to three. Plants were grown vertically with a single stem and pinched at the second upper leaf above the second truss. Air temperature and relative humidity (RH) were measured using a data logger (TR-72Ui; T and D, Japan) every $30 \mathrm{~min}$. with sensor in a ventilation tube $1.8 \mathrm{~m}$ in height. Daily mean temperatures and $\mathrm{RH}$ are shown in Figure 1.

The tomato plants were exposed to four treatments of a combination of two kinds of fertilizer and two levels of salinity. Sixteen $\mathrm{g}$ of controlled release fertilizer [100 days-release type, N:P:K=13:9:11 (\%); JCAM Agri., Japan] and $12 \mathrm{~g}$ of calcium sulfate were applied three times per plant as a chemical fertilizer treatment (CF), and an organo-mineral fertilizer containing the same amount of $\mathrm{N}$ with $\mathrm{CF}$ was applied three times as an OMF treatment. The first application of fertilizer was mixed with the medium prior to transplant. The first supplemental application was put on the soil surface at 21 and 28 DAT, and the second was applied at 47 and 49 DAT (in summer cropping and winter cropping, respectively). The OMF used in this research was generated by mixing calcium sulfate, ground rice bran (a byproduct of the rice milling process), and humic acid [Canadian Humin $\mathrm{HNC}^{\circledR}$, N:P:K = 1.26:0.17:0.05 (\%), total humic substances $70 \%<$; PIC-BIO, Japan] at a ratio of 2:10:1 (w/w) following Rady (2012). Salinity treatment was applied by adding $\mathrm{NaCl}$ in the irrigation water up to $50 \mathrm{mM}$ from a few days after the fruit setting treatment of the first cluster (25 and 38 DAT, in summer cropping and in winter cropping, respectively) to the end of the culture. Each treatment involved ten plants.

For about 3 plants randomly selected from each treatment after 24 (summer cropping) and 21 (winter cropping) days of salinity treatment, the leaf just above the first truss was collected to determine the proline contents as described by Bates et al. (1973). Approximately $0.5 \mathrm{~g}$ of the leaf was homogenized in $10 \mathrm{~mL}$ of $3 \%$ aqueous sulfosalicylic acid and filtered. Filtrate was reacted with acid ninhydrin and glacial acetic acid for $1 \mathrm{~h}$ at $100^{\circ} \mathrm{C}$. The reaction mixture was extracted with toluene and the absorbance at $520 \mathrm{~nm}$ of the toluene extraction was read to determine the proline concentration. Residues of plant were divided into leaves, stems, and fruits and weighed, followed by drying in an oven at $80^{\circ} \mathrm{C}$ to determine the dry weight and elemental concentrations. Ground samples were subjected to wet degradation followed by quantitative analysis of $\mathrm{K}, \mathrm{Mg}$, $\mathrm{Ca}$, and $\mathrm{Na}$ by flame atomic absorption spectrophotometry (polarized Zeeman atomic absorption spectrophotometer Z-2000; Hitachi, Japan) and P by using a molybdenum blue method.

The remaining plants were grown until all fruits of the first and second trusses matured to evaluate the BER incidence and to determine the contents of sugar,

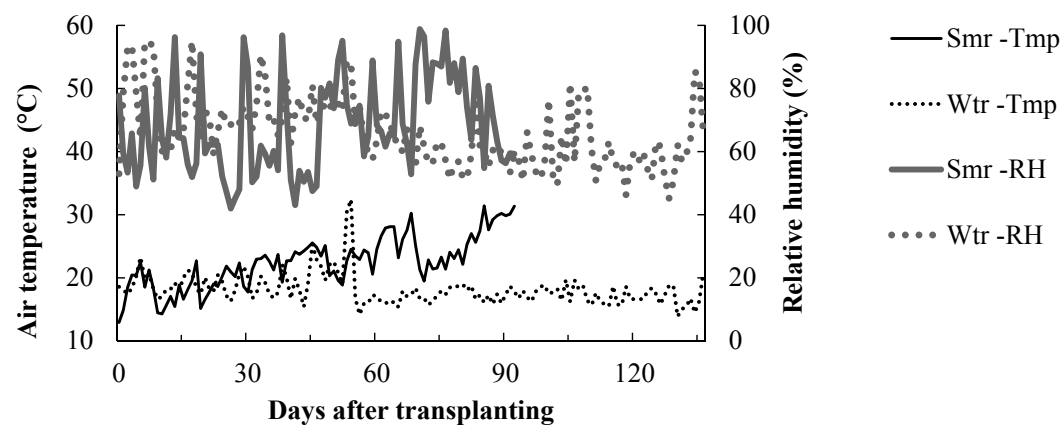

Fig. 1. Daily mean air temperature (Tmp) and relative humidity (RH) during the experimental period in Exp. 1. Smr, summer cropping; Wtr, winter cropping. 
ascorbic acid, glutamic acid, and $\mathrm{Na}$ at the full maturity stage. A quarter of each fruit divided radially was homogenized, and the ascorbic acid contents were measured by means of a reflectometer (RQflex plus 10; Merck, Germany) with an ascorbic acid test (Reflectoquant ascorbic acid test; Kanto Kagaku, Japan) done by following the instructions. Fruit residues were stocked at $-20^{\circ} \mathrm{C}$ until the analysis of sugar, glutamic acid, and Na contents. Soluble sugars were determined by high performance liquid chromatography (HPLC) with an RI detector, using an SC1011 column (Shodex, Japan) at $80^{\circ} \mathrm{C}$ with water $\left(1 \mathrm{~mL} \cdot \mathrm{min}^{-1}\right)$ as the eluate. Glutamic acid contents were determined using the reflectometer with a glutamic acid test (Agrocheck glutamic acid test; Kanto Kagaku) done by following the instructions. Na contents were determined by quantitative analysis using flame atomic absorption spectrophotometry.

\section{Exp. 2. Suitable amount of OMF under salinity}

Seeds of the tomato 'House Momotaro' were sown in seed trays with nursery soil on 11 March 2014 in a greenhouse without heating. Seedlings were fertilized with a nutrient solution (a half strength of the A-type recipe of Otsuka House Solution; Otsuka Chemical Co., Ltd.) every 2 days. On 29 April, each seedling was transplanted to a plastic pot (diameter $10.5 \mathrm{~cm}$ ) containing a decomposed granite soil-perlite-sphagnum peat mixture $(3: 1: 1, \mathrm{v} / \mathrm{v})$, and transplanted to a $5000^{-1}-\mathrm{a}$ Wagner pot containing the same medium on 30 May. The composition of OMF used in this experiment was the same as in Exp. 1. Before use, water with a $10^{-1}$ volume of OMF was added followed by mixing every other day for two weeks or more for aerobic fermentation. Treatments were as follows. (i) $16 \mathrm{~g}$ of controlled

Table 1. Amount of nutrients (g) applied per plant in Exp. 2.

\begin{tabular}{lcrrrrc}
\hline \hline \multicolumn{1}{c}{ Treatment } & $\mathrm{N}$ & \multicolumn{1}{c}{$\mathrm{P}$} & $\mathrm{K}$ & $\mathrm{Ca}$ & $\mathrm{Fe}$ & $\mathrm{Mn}$ \\
\hline $\mathrm{CF}$ & 6.5 & 4.7 & 5.5 & 9.8 & 0.11 & 0.05 \\
$\mathrm{O} 3-1, \mathrm{O} 1-3$ & 6.5 & 16.4 & 6.5 & 9.8 & 1.11 & 0.02 \\
O1.5-3, O4.5-1 & 9.7 & 24.6 & 9.7 & 14.7 & 1.66 & 0.04 \\
\hline
\end{tabular}

release fertilizer and $12 \mathrm{~g}$ of calcium sulfate were applied three times per plant as a control (CF), (ii) OMF containing the same amount of $\mathrm{N}$ with $\mathrm{CF}$ was applied 3 times (O1-3), (iii) OMF containing one and a half times the amount of $\mathrm{N}$ with $\mathrm{CF}$ was applied three times (O1.5-3), (iv) OMF containing three times the amount of $\mathrm{N}$ with a dose of $\mathrm{CF}$ was applied once (O3-1), and (v) OMF containing four and a half times the amount of $\mathrm{N}$ with a dose of $\mathrm{CF}$ was applied once (O4.5-1). The total amount of major elements per plant is shown in Table 1. The first application of fertilizer was mixed with the medium prior to transplant, and supplemental applications were put on the soil surface at 22 and 38 DAT. Plants were grown and exposed to salinity treatment from 6 June (7 DAT) similarly to Exp.1. 4-CPA solution was sprayed for setting on 30 May (0 DAT) to the first trusses and on 10 June (11 DAT) to the second trusses. Each treatment involved four plants.

At 14 DAT, the plant height, true leaf number, and the length and width of the leaves just below the second truss were measured. Twenty $\mathrm{mL}$ of soil taken from a depth of 5 to $10 \mathrm{~cm}$ was mixed with $20 \mathrm{~mL}$ of distilled water to evaluate the $\mathrm{NO}_{3}{ }^{-}$and $\mathrm{NH}_{4}{ }^{+}$concentration of the soil solution two and three weeks after transplanting. $\mathrm{NO}_{3}^{-}$was measured by using a nitrate ion meter (B-742; Horiba, Japan), and $\mathrm{NH}_{4}^{+}$was measured by using an RQ-flex reflectometer with ammonium test strips (Merck). All fruits of the first and second trusses were harvested at the full maturity stage and weighed. Daily mean temperatures and RH are shown in Figure 2.

Exp.3. Effects of salinity and OMF on fruit Ca concentration in fractions in relation to BER occurrence

Seeds of the tomato 'House Momotaro' were sown on 23 January 2015. Each seedling was transplanted to a plastic pot (diameter of $9 \mathrm{~cm}$ ) on 17 February, transplanted to a $5000^{-1}$-a Wagner pot on 2 April, and cultivated in the same way as Exp. 1. The tomato plants were exposed to four treatments of a combination of two fertilizers and two levels of salinity in the same way as in Exp. 1 except that the OMF was used after aerobic fermentation in advance and the total amount

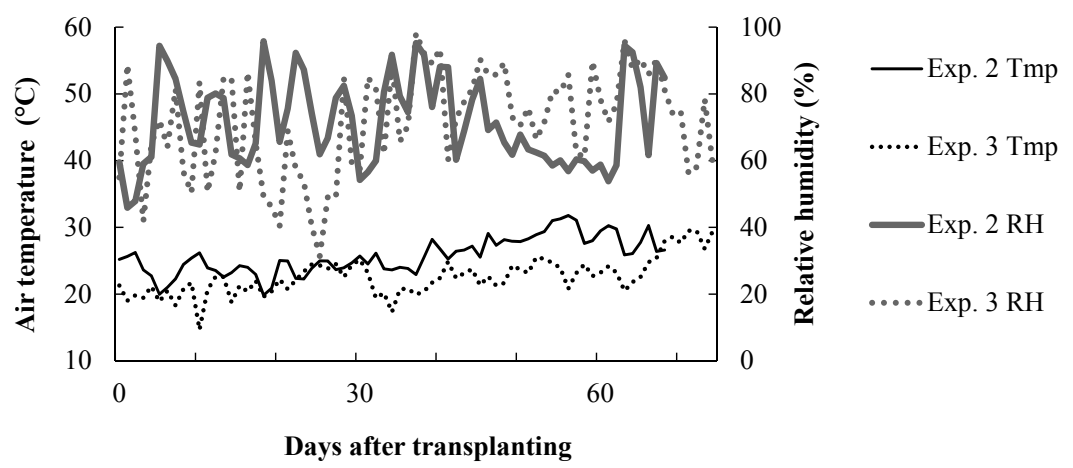

Fig. 2. Daily mean air temperature (Tmp) and relative humidity (RH) during the experimental period in Exps. 2 and 3. 
was increased to $195 \mathrm{~g}$. Each treatment involved six plants. Plants were cultured and exposed to salinity treatment similarly to Exp. 1. Salinity treatment was applied from 16 April (14 DAT). 4-CPA solution was sprayed for setting on 16 April (14 DAT) to the first trusses and on 21 May (5 days of salinity treatment) to the second trusses. Daily mean temperatures and RH are shown in Figure 2.

The second fruits of the second truss were taken three weeks after anthesis (26 days after starting salinity) and weighed. The distal half of each fruit was cut into segments to evaluate the $\mathrm{Ca}$ concentration. Sequential calcium extraction and determination were conducted according to Yoshida et al. (2014). The Ca concentration was determined by atomic absorption spectrometry (Z-6000; Hitachi) and described using $\mu \mathrm{mol} \cdot \mathrm{g}^{-1} \mathrm{FW}$. The remaining fruits of the first and second trusses were harvested at the full maturity stage to evaluate the BER and fresh weight.

\section{Statistical analysis}

Data were analyzed for statistical significance using the JSTAT Version 16.1 [Copyright(C) of M. Sato, 1998-2014], with a two-way ANOVA and Tukey's test.

\section{Results}

Exp. 1. Effects of OMF and salinity on plant growth and mineral absorption

The plant growth with OMF was less than that with CF for both the summer cropping (Table 2) and the winter cropping (Table 3 ). Salinity did not significantly affect the leaf and stem fresh weight. The dry matter ratio tended to be higher under salinity in the summer cropping, but not different in the winter cropping.

Leaves from plants grown with OMF contained higher levels of $\mathrm{K}$ and $\mathrm{P}$ than those with $\mathrm{CF}$ both in the summer and winter cropping, but were not affected by salinity. The $\mathrm{Mg}$ content was decreased by salinity in the summer cropping, but not in the winter cropping. The Na content of leaves was clearly increased by the salinity treatment in $\mathrm{CF}$, but not so much in OMF. OMF

Table 2. Leaf, stem, and fruit fresh weight per plant, dry matter ratio of leaf, stem, and fruit, leaf proline contents, and $\mathrm{K}, \mathrm{Mg}, \mathrm{Ca}, \mathrm{Na}$, and $\mathrm{P}$ contents per dry weight of tomato plants grown with chemical fertilizer (CF) or organo-mineral fertilizer (OMF) with/without 24 days of salinity treatment 49 days after being trasplanted in summer cropping in Exp. 1.

\begin{tabular}{|c|c|c|c|c|c|c|c|c|c|c|c|c|c|c|c|c|c|c|c|c|c|c|c|}
\hline \multirow[t]{2}{*}{ Fertilizer } & \multirow[t]{2}{*}{ Salinity } & \multicolumn{3}{|c|}{$\begin{array}{c}\text { Fresh weight } \\
(\mathrm{g})\end{array}$} & \multicolumn{3}{|c|}{$\begin{array}{c}\text { Dry matter ratio } \\
(\%)\end{array}$} & \multirow{2}{*}{$\begin{array}{l}\text { Leaf proline } \\
\text { content } \\
\left(\mu \mathrm{g} \cdot \mathrm{g}^{-1} \mathrm{FW}\right)\end{array}$} & \multicolumn{5}{|c|}{$\begin{array}{c}\text { Leaf } \\
\left(\mathrm{mg} \cdot \mathrm{g}^{-1} \mathrm{DW}\right)\end{array}$} & \multicolumn{5}{|c|}{$\begin{array}{c}\text { Stem } \\
\left(\mathrm{mg} \cdot \mathrm{g}^{-1} \mathrm{DW}\right)\end{array}$} & \multicolumn{5}{|c|}{$\begin{array}{c}\text { Fruit } \\
\left(\mathrm{mg} \cdot \mathrm{g}^{-1} \mathrm{DW}\right)\end{array}$} \\
\hline & & Leaf & Stem & Fruit & Leaf & Stem & Fruit & & $\mathrm{K}$ & $\mathrm{Mg}$ & $\mathrm{Ca}$ & $\mathrm{Na}$ & $\mathrm{P}$ & $\mathrm{K}$ & $\mathrm{Mg}$ & $\mathrm{Ca}$ & $\mathrm{Na}$ & $\mathrm{P}$ & $\mathrm{K}$ & $\mathrm{Mg}$ & $\mathrm{Ca}$ & $\mathrm{Na}$ & $\mathrm{P}$ \\
\hline \multirow[t]{2}{*}{$\mathrm{CF}$} & Water & 101 & 49 & 317 & 13.5 & 14.7 & 7.9 & 0.200 & 19.3 & 12.9 & 31.6 & 3.7 & 14.5 & 33.6 & 3.6 & 10.0 & 1.9 & 11.3 & 32.4 & 1.7 & 1.9 & 0.8 & 11.4 \\
\hline & Salinity & 115 & 51 & 137 & 13.1 & 16.1 & 12.5 & 0.995 & 21.0 & 9.2 & 33.7 & 18.8 & 12.4 & 24.3 & 3.3 & 8.8 & 7.6 & 11.0 & 31.7 & 1.6 & 1.8 & 3.3 & 10.8 \\
\hline \multirow[t]{2}{*}{$\mathrm{OMF}$} & Water & 38 & 32 & 145 & 14.0 & 14.1 & 7.5 & 0.169 & 39.1 & 11.4 & 27.4 & 1.9 & 25.5 & 42.5 & 4.8 & 8.6 & 1.6 & 15.5 & 42.0 & 2.2 & 2.3 & 0.8 & 14.3 \\
\hline & Salinity & 35 & 29 & 103 & 15.0 & 16.9 & 10.5 & 0.337 & 36.3 & 8.6 & 28.4 & 5.6 & 28.4 & 36.0 & 4.0 & 8.2 & 4.9 & 15.0 & 41.3 & 1.9 & 2.6 & 1.6 & 12.1 \\
\hline \multicolumn{24}{|c|}{ Two-way ANOVA } \\
\hline & Fertilizer & $* *$ & $* *$ & $* *$ & $* *$ & NS & $* *$ & $* *$ & $* *$ & NS & $*$ & $* *$ & $* *$ & $* *$ & $* *$ & NS & $*$ & $* *$ & $* *$ & $* *$ & $*$ & $* *$ & $*$ \\
\hline & Salinity & NS & NS & $* *$ & NS & $* *$ & $* *$ & $* *$ & NS & $* *$ & NS & $* *$ & NS & $*$ & $*$ & NS & $* *$ & NS & NS & $* *$ & NS & $* *$ & NS \\
\hline & Interaction & $*$ & NS & $* *$ & NS & NS & $*$ & $* *$ & NS & NS & NS & $* *$ & NS & NS & NS & NS & NS & NS & NS & NS & NS & $* *$ & NS \\
\hline
\end{tabular}

${ }^{\mathrm{z}} \mathrm{NS}, *$, and $* *$ indicate non-siginificant, siginificant at $P<0.05$, and $<0.01$, respectively $(\mathrm{n}=3)$.

Table 3. Leaf, stem, and fruit fresh weight per plant, dry matter ratio of leaf, stem, and fruit, leaf proline contents, and $\mathrm{K}$, $\mathrm{Mg}$, Ca, $\mathrm{Na}$, and $\mathrm{P}$ contents per dry weight of tomato plants grown with chemical fertilizer (CF) or organo-mineral fertilizer (OMF) with/without 21 days of salinity treatment 59 days after being trasplanted in winter cropping in Exp. 1.

\begin{tabular}{|c|c|c|c|c|c|c|c|c|c|c|c|c|c|c|c|c|c|c|c|c|c|c|c|}
\hline \multirow[t]{2}{*}{ Fertilizer } & \multirow[t]{2}{*}{ Treatment } & \multicolumn{3}{|c|}{$\begin{array}{l}\text { Fresh weight } \\
(\mathrm{g})\end{array}$} & \multicolumn{3}{|c|}{$\begin{array}{c}\text { Dry matter ratio } \\
(\%)\end{array}$} & \multirow{2}{*}{$\begin{array}{l}\text { Leaf proline } \\
\text { content } \\
\left(\mu \mathrm{g} \cdot \mathrm{g}^{-1} \mathrm{FW}\right)\end{array}$} & \multicolumn{5}{|c|}{$\begin{array}{c}\text { Leaf } \\
\left(\mathrm{mg} \cdot \mathrm{g}^{-1} \mathrm{DW}\right)\end{array}$} & \multicolumn{5}{|c|}{$\begin{array}{c}\text { Stem } \\
\left(\mathrm{mg} \cdot \mathrm{g}^{-1} \mathrm{DW}\right)\end{array}$} & \multicolumn{5}{|c|}{$\begin{array}{c}\text { Fruit } \\
\left(\mathrm{mg} \cdot \mathrm{g}^{-1} \mathrm{DW}\right)\end{array}$} \\
\hline & & Leaf & Stem & Fruit & Leaf & Stem & Fruit & & $\mathrm{K}$ & $\mathrm{Mg}$ & $\mathrm{Ca}$ & $\mathrm{Na}$ & $\mathrm{P}$ & K & $\mathrm{Mg}$ & $\mathrm{Ca}$ & $\mathrm{Na}$ & $\mathrm{P}$ & $\mathrm{K}$ & $\mathrm{Mg}$ & $\mathrm{Ca}$ & $\mathrm{Na}$ & $\mathrm{P}$ \\
\hline \multirow[t]{2}{*}{$\mathrm{CF}$} & Water & 143 & 77 & 33 & 11.9 & 12.2 & 10.1 & 0.007 & 25.4 & 6.5 & 24.4 & 4.8 & 13.9 & 29.5 & 3.2 & 10.4 & 4.6 & 12.4 & 35.7 & 2.0 & 3.8 & 3.6 & 13.3 \\
\hline & Salinity & 123 & 60 & 76 & 12.1 & 14.5 & 12.6 & 0.023 & 28.9 & 6.8 & 26.0 & 11.1 & 14.3 & 27.3 & 3.2 & 11.2 & 7.7 & 11.9 & 33.0 & 1.7 & 2.0 & 5.0 & 11.0 \\
\hline \multirow[t]{2}{*}{ OMF } & Water & 31 & 33 & 26 & 11.5 & 11.8 & 10.7 & 0.002 & 42.4 & 8.6 & 19.8 & 3.7 & 34.0 & 48.1 & 3.7 & 8.0 & 3.9 & 18.7 & 46.4 & 3.2 & 3.3 & 3.3 & 16.2 \\
\hline & Salinity & 34 & 30 & 25 & 13.4 & 10.6 & 9.2 & 0.022 & 42.8 & 8.1 & 17.3 & 7.3 & 35.4 & 49.8 & 3.4 & 7.0 & 8.1 & 19.5 & 44.5 & 2.6 & 2.5 & 4.5 & 14.5 \\
\hline \multicolumn{24}{|c|}{ Two-way ANOVA ${ }^{\mathrm{Z}}$} \\
\hline & Fertilizer & $* *$ & $* *$ & NS & NS & NS & NS & NS & ** & $*$ & $* *$ & $* *$ & ** & $* *$ & $*$ & $* *$ & NS & $* *$ & $* *$ & $*$ & NS & $*$ & $*$ \\
\hline & Salinity & NS & NS & NS & NS & NS & NS & * & NS & NS & NS & $* *$ & NS & NS & NS & NS & $* *$ & NS & NS & NS & NS & $* *$ & NS \\
\hline & Interaction & * & NS & NS & NS & NS & NS & NS & NS & NS & $*$ & $* *$ & NS & NS & NS & NS & $* *$ & NS & NS & NS & NS & NS & NS \\
\hline
\end{tabular}

${ }^{\mathrm{Z}} \mathrm{NS}, *$, and $* *$ indicate non-siginificant, siginificant at $P<0.05$, and $<0.01$, respectively $(\mathrm{n}=3)$. 
Table 4. Contents of ascorbic acid (AsA), sucrose (Suc), glucose (Gluc), fructose (Fru), glutamic acid, and sodium (Na) of mature fruit from the second truss of tomato plants grown with chemical (CF) or organo-mineral (OMF) fertilizer under salinity in Exp. 1. Smr, summer cropping; Wtr, winter cropping.

\begin{tabular}{|c|c|c|c|c|c|c|c|c|c|c|c|c|c|}
\hline \multirow[t]{2}{*}{ Fertilizer } & \multirow[t]{2}{*}{ Treatment } & \multicolumn{2}{|c|}{$\begin{array}{c}\text { AsA } \\
\left(\mathrm{mg} \cdot \mathrm{g}^{-1} \mathrm{FW}\right)\end{array}$} & \multicolumn{2}{|c|}{$\begin{array}{c}\begin{array}{c}\text { Suc } \\
\left(\mathrm{mg} \cdot \mathrm{g}^{-1} \mathrm{FW}\right)\end{array} \\
\end{array}$} & \multicolumn{2}{|c|}{$\begin{array}{c}\text { Gluc } \\
\left(\mathrm{mg} \cdot \mathrm{g}^{-1} \mathrm{FW}\right)\end{array}$} & \multicolumn{2}{|c|}{$\begin{array}{c}\text { Fru } \\
\left(\mathrm{mg} \cdot \mathrm{g}^{-1} \mathrm{FW}\right) \\
\end{array}$} & \multicolumn{2}{|c|}{$\begin{array}{c}\text { Glutamic acid } \\
\left(\mathrm{mg} \cdot \mathrm{g}^{-1} \mathrm{FW}\right)\end{array}$} & \multicolumn{2}{|c|}{$\begin{array}{c}\mathrm{Na} \\
\left(\mathrm{mg} \cdot \mathrm{g}^{-1} \mathrm{FW}\right)\end{array}$} \\
\hline & & Smr & Wtr & Smr & Wtr & Smr & Wtr & Smr & Wtr & Smr & Wtr & Smr & Wtr \\
\hline \multirow[t]{2}{*}{$\mathrm{CF}^{\mathrm{z}}$} & Water & 0.29 & 0.25 & 0.3 & 0.7 & 20 & 28 & 20 & 26 & 163 & 190 & 4.0 & 1.3 \\
\hline & Salinity & 0.43 & 0.28 & 1.4 & 2.1 & 31 & 36 & 29 & 34 & 387 & 304 & 31.5 & 15.1 \\
\hline \multirow[t]{2}{*}{$\mathrm{OMF}^{\mathrm{y}}$} & Water & 0.32 & 0.25 & 0.3 & 0.1 & 18 & 22 & 20 & 23 & 131 & 113 & 0.7 & 1.1 \\
\hline & Salinity & 0.44 & 0.38 & 3.4 & 2.1 & 27 & 35 & 26 & 33 & 403 & 241 & 17.0 & 3.4 \\
\hline \multicolumn{14}{|c|}{ Two-way ANOVA ${ }^{x}$} \\
\hline & Fertilizer & NS & $*$ & $*$ & NS & $*$ & NS & NS & NS & NS & NS & NS & NS \\
\hline & Salinity & $* *$ & $* *$ & $* *$ & $*$ & $* *$ & $* *$ & $* *$ & $* *$ & $* *$ & $* *$ & $* *$ & $* *$ \\
\hline & Interaction & NS & $*$ & $*$ & NS & NS & NS & NS & NS & NS & NS & NS & $* *$ \\
\hline
\end{tabular}

${ }^{\mathrm{z}} \mathrm{CF}, 16 \mathrm{~g}$ of controlled release fertilizer and $12 \mathrm{~g}$ of calcium sulfate per plant applied three times.

y $\mathrm{OMF}, 77 \mathrm{~g}$ of organo-mineral fertilizer per plant applied three times.

${ }^{x} \mathrm{NS}, *$, and $* *$ indicate non-siginificant, siginificant at $P<0.05$, and $<0.01$, respectively $(\mathrm{n}=6)$.

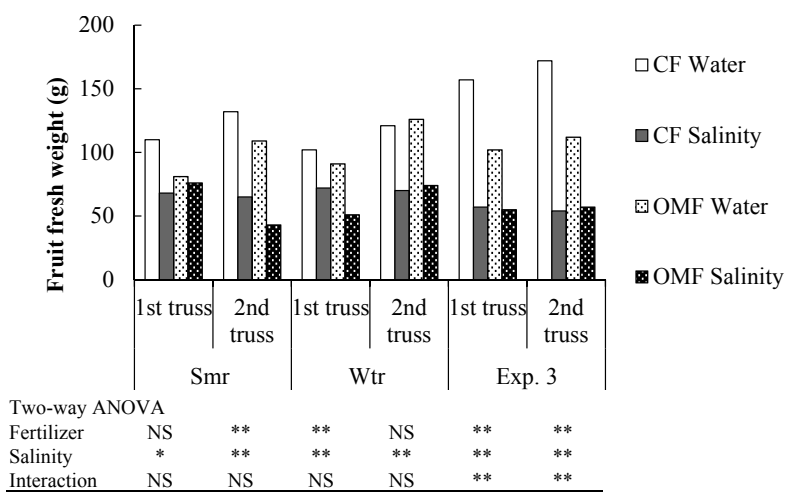

Fig. 3. Mature fruit weight from tomato plants grown with chemical $(\mathrm{CF})$ or organo-mineral (OMF) fertilizer under salinity in Exps. 1 and 3. Smr, summer cropping; Wtr, winter cropping. $\mathrm{NS}, *$, and $* *$ indicate non-significant, significant at $P<0.05$, and $<0.01$, respectively.

tended to decrease the proline content in both cropping times, but did so insignificantly in winter cropping.

\section{Fruit qualities and BER in Exp. 1}

Salinity treatment caused a significant increase in ascorbic acid, sucrose, glucose, fructose, and glutamic acid (Table 4). There was no effect from fertilizer on the increasing sugar concentration under the salinity condition, except for sucrose and glucose in the summer cropping. The content of glutamic acid was higher in $\mathrm{CF}$ than in OMF. The Na content in mature fruit in the CF-salinity treatment was the highest among all treatments. The mature fruit weight in OMF was less than that in CF and was decreased by salinity (Fig. 3). The incidence of BER was lower in OMF-salinity than in CF-salinity, which was the highest of all (Fig. 4). Namely, tomato plants grown with OMF had smaller fruits than with CF, but the incidence of BER under salinity was reduced by OMF treatment.

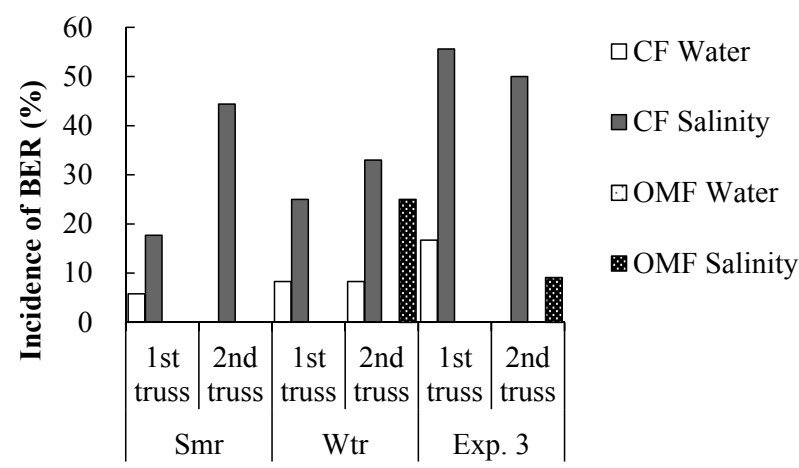

Fig. 4. Incidence of blossom-end-rot (BER) in tomato plants grown with chemical (CF) or organo-mineral (OMF) fertilizer under salinity in Exps. 1 and 3. Smr, summer cropping; Wtr, winter cropping.

\section{Exp. 2. Suitable amount of OMF under salinity}

The plants grown with $\mathrm{CF}$ were the largest in terms of leaf size, but were not significantly taller than the others at two weeks after transplanting, except for O4.5-1 (Table 5). The $\mathrm{NO}_{3}^{-}$concentration of the soil solution was the highest in CF and the lowest in O4.5-1, and the $\mathrm{NH}_{4}^{+}$concentration was extremely high in O4.5-1. The inferior growth of plants with O4.5-1 was assumed to be caused by the low- $\mathrm{NO}_{3}{ }^{-}$and high- $\mathrm{NH}_{4}{ }^{+}$ concentration of the soil. The mature fruit of the first truss was not different among the treatments in terms of weight. In the second truss, the fruit weight in the O1.5-3 treatment was similar to that in $\mathrm{CF}$ and relatively large in all the OMF treatments. Because nutrient release from OMF may be slower than that from $\mathrm{CF}$, a suitable amount of OMF for plant growth should be greater than that of chemical fertilizer. Therefore, we decided the amount of OMF applied in Exp. 3 to be one and a half times the $\mathrm{N}$ amount of chemical fertilizer. 
Table 5. Effects of amount of organo-mineral fertilizer (OMF) on plant height and leaf size just below the first truss after a week of salinity treatment, $\mathrm{NO}_{3}{ }^{-}$and $\mathrm{NH}_{4}{ }^{+}$ion concentration of soil water, and fruit fresh weight at ripening in Exp. 2.

\begin{tabular}{|c|c|c|c|c|c|c|c|c|c|}
\hline & \multicolumn{3}{|c|}{$\begin{array}{l}\text { Plant growth after a week of salinity } \\
\qquad(\mathrm{cm})\end{array}$} & \multicolumn{2}{|c|}{$\begin{array}{c}\mathrm{NO}_{3}^{-} \text {in soil } \\
(\mathrm{ppm})^{\mathrm{z}}\end{array}$} & \multicolumn{2}{|c|}{$\begin{array}{c}\mathrm{NH}_{4}^{+} \text {in soil } \\
(\mathrm{ppm})^{\mathrm{z}}\end{array}$} & \multicolumn{2}{|c|}{$\begin{array}{l}\text { Fruit fresh weight at } \\
\text { ripening }(\mathrm{g})\end{array}$} \\
\hline & Plant height & Leaf length & Leaf width & 1 week & 2 weeks & 1 week & 2 weeks & 1 st truss & 2nd truss \\
\hline CF1-3 & $85 \mathrm{a}$ & $32 \mathrm{a}$ & $29 \mathrm{a}$ & $40.9 \mathrm{a}$ & $45.8 \mathrm{ab}$ & $0.5 \mathrm{c}$ & $0.5 \mathrm{~b}$ & $57.7 \mathrm{a}$ & $58.3 \mathrm{a}$ \\
\hline O1-3 & $78 \mathrm{ab}$ & $26 \mathrm{bc}$ & $21 \mathrm{bc}$ & $36.2 \mathrm{ab}$ & $37.4 \mathrm{bc}$ & $0.6 \mathrm{c}$ & $1.0 \mathrm{~b}$ & $63.6 \mathrm{a}$ & $36.5 \mathrm{~b}$ \\
\hline O1.5-3 & $82 \mathrm{ab}$ & $27 \mathrm{~b}$ & $24 \mathrm{~b}$ & $34.2 \mathrm{~b}$ & $43.4 \mathrm{abc}$ & $2.4 \mathrm{c}$ & $1.3 \mathrm{~b}$ & $66.8 \mathrm{a}$ & $45.9 \mathrm{ab}$ \\
\hline O3-1 & $75 \mathrm{ab}$ & $25 \mathrm{bc}$ & $21 \mathrm{c}$ & $34.5 \mathrm{~b}$ & $47.6 \mathrm{a}$ & $24.0 \mathrm{~b}$ & $7.9 \mathrm{~b}$ & $65.4 \mathrm{a}$ & $37.1 \mathrm{~b}$ \\
\hline O4.5-1 & $70 \mathrm{~b}$ & $23 \mathrm{c}$ & $16 \mathrm{~d}$ & $32.6 \mathrm{~b}$ & $33.8 \mathrm{c}$ & $47.5 \mathrm{a}$ & $67.0 \mathrm{a}$ & $48.5 \mathrm{a}$ & $36.6 \mathrm{~b}$ \\
\hline
\end{tabular}

Within each column, different letters indicate significant differences with Tukey's test at $P<0.05(\mathrm{n}=4)$. CF1-3, 16 g of controlled release fertilizer and $12 \mathrm{~g}$ of calcium sulfate per plant applied three times; O1-3, OMF containing the same amount of $\mathrm{N}$ with CF applied three times; O1.5-3, OMF containing one and a half times the amount of $\mathrm{N}$ with $\mathrm{CF}$ applied three times; O3-1, OMF containing three times the amount of $\mathrm{N}$ with $\mathrm{CF}$ applied once; O4.5-1, OMF containing four and a half times the amount of $\mathrm{N}$ with $\mathrm{CF}$ applied once.

${ }^{\mathrm{z}}$ Concentration of the supernatant was mearsured from a mixture of $20 \mathrm{~mL}$ soil and $20 \mathrm{~mL}$ distilled water.

Exp. 3. Effects of salinity and $O M F$ on fruit calcium concentration in fractions in relation to BER occurrence

The mature fruit weight in OMF was less than that in $\mathrm{CF}$ and was decreased by salinity (Fig. 3). The incidence of BER was low in OMF-salinity, and the highest in CF-salinity (Fig. 4). The water-soluble Ca concentration in the distal half of tomato fruit was significantly reduced by salinity treatment, although there was no significant difference either in $\mathrm{NaCl}$-soluble or $\mathrm{HCl}$ soluble $\mathrm{Ca}$ concentrations among the treatments (Fig. 5).

\section{Discussion}

We used drop irrigation of $50 \mathrm{mM}$ of $\mathrm{NaCl}$ as the salinity treatment in this study. Based on the results, namely, reduced plant growth, increased dry matter ratio, increased sugar contents of the fruit, increased proline contents, and enhanced incidence of BER, indicated tomato plants to experienced sufficient salinity stress. Salinity treatment caused an increase in ascorbic acid, sucrose, glucose, fructose, and glutamic acid (Table 4), as shown in other reports (Saito et al., 2006, 2008; Zushi et al., 2005).

The proline content of leaves was increased by the salinity treatment in association with an increase in the $\mathrm{Na}$ content. The biosynthesis of proline is assumed to be promoted by the increase in $\mathrm{Na}$ concentration (Bates et al., 1973). Moreover, OMF treatment reduced both the $\mathrm{Na}$ and proline concentrations, suggesting that $\mathrm{OMF}$ treatment inhibits the accumulation of $\mathrm{Na}$ in the leaves. However, it was not very effective in stems and fruits in comparison with leaves. Therefore, OMF may reduce proline synthesis by inhibiting the accumulation of $\mathrm{Na}$ in leaves.

The induction of BER in young fruit under the high salinity condition was most likely promoted by the reduction in $\mathrm{Ca}$ absorption by roots and transportation to the fruit, resulting in a shortage of $\mathrm{Ca}$ for rapid cell growth in the distal portion of tomato fruits (Ho and

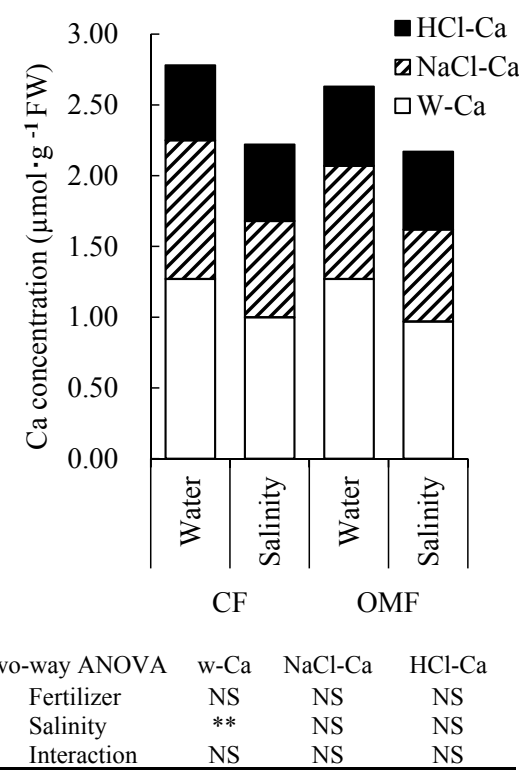

Fig. 5. Water-, $\mathrm{NaCl}-$, and $\mathrm{HCl}$-soluble $\mathrm{Ca}$ concentration in the distal half of immature fruit (3 weeks after anthesis) from plants grown with chemical (CF) or organo-mineral (OMF) fertilizer under salinity in Exp. 3. W-Ca, 99\% ethanol and water soluble fraction; $\mathrm{NaCl}-\mathrm{Ca}, 1 \mathrm{~N} \mathrm{NaCl}$ soluble fraction; $\mathrm{HCl}-\mathrm{Ca}, 0.6 \mathrm{~N}$ $\mathrm{HCl}$ soluble fraction. NS and ** indicate non-significant and significant at $P<0.01$, respectively $(\mathrm{n}=6)$.

White, 2005). However, in this research, Mg uptake was reduced after three weeks of salinity, but $\mathrm{Ca}$ was not clearly reduced. Similar results were obtained by Giuffrida et al. (2009), who reported that salinity does not cause a reduction in the amount of main macronutrients, including $\mathrm{Ca}$, to deficiency levels that influence the growth processes, except in the case of potassium. Hidaka et al. (2009) also showed that the Ca concentration in xylem sap is not reduced by short-term salt stress treatment in the NFT system. In the present study, the total $\mathrm{Ca}$ contents of the leaves and stems were not affected by the salinity for at least three weeks (Table 2, 3). Therefore, the salinity should not have an 
effect on the uptake of $\mathrm{Ca}$. Since the water soluble $\mathrm{Ca}$ content of the distal half of the young tomato fruit was significantly decreased by the salinity treatment (Fig. 5), salinity likely affects the translocation, localization, or distribution of chemical forms of $\mathrm{Ca}$.

However, the water soluble $\mathrm{Ca}$ content was not as low as the critical point suggested by Yoshida et al. (2014), at which the risk for BER increases when the water-soluble $\mathrm{Ca}$ concentration in the distal half of young tomato fruits drops below $0.20 \mu \mathrm{mol} \cdot \mathrm{g}^{-1} \mathrm{FW}$. The calcium sulphate included in the CF and OMF used in the present study could maintain the Ca level of fruits because supplemental calcium sulphate added to a nutrient solution containing salt significantly improved growth, increased leaf $\mathrm{K}^{+}, \mathrm{Ca}^{2+}$, and $\mathrm{N}$, and reduced the concentration of $\mathrm{Na}^{+}$in tomato plants (Tuna et al., 2007).

Although the incidence of BER under salinity was significantly lower in OMF than in CF (Fig. 4), there was no difference in $\mathrm{Ca}$ concentration in either fraction between CF-salinity and OMF-salinity treatments (Fig. 5). These results suggest that the reduction in BER incidence by OMF treatment cannot be explained by the difference in $\mathrm{Ca}$ concentration. Otherwise, BER is considered to be associated with large fruit grown under conditions favorable for fruit expansion (Ho and White, 2005). However, the fruit in OMF was not smaller than that in $\mathrm{CF}$ under salinity, suggesting that they were the same in terms of fruit growth, but different in terms of BER incidence.

Saure (2014) concluded that $\mathrm{Ca}^{2+}$ deficiency is not the cause, but the result, of BER and that the first step in the development of BER is the production of reactive oxygen species increased by stress. In peppers, antioxidants are related to blossom-end rot (Turhan et al., 2006). It may be possible that the reduction in BER incidence by OMF under salinity in the present study was caused by an enhanced antioxidant system. Tomato fruits from organic farming are higher in superoxide dismutase activity (Oliveira et al., 2013), and the significant increase in the ascorbic acid contents of mature fruit in the winter cropping of Exp. 1 with OMF could show a correlation with this.

Otherwise, abscisic acid (ABA) could be considered to be associated with BER reduction caused by OMF. ABA completely prevented BER development (de Freitas et al., 2011). In the present experiments, the plants grown in OMF were smaller than those in $\mathrm{CF}$, even if the amount of OMF was increased (Exp. 2). Because the ground rice bran used in OMF originated from rice seed, in which native $\mathrm{ABA}$ is contained (Hayashi, 1976, 1979), OMF should contain ABA. Additionally, it is possible that OMF enhances ABA biosynthesis in tomatoes as well.

Therefore, further studies are necessary to understand the mechanism of the reduction in BER incidence with OMF.

\section{Acknowledgements}

The authors gratefully acknowledge the help received on the analysis of the minerals from Dr. Ueno and Dr. Toma of the Laboratory of Soil Fertility Science at Ehime University.

\section{Literature Cited}

Bates, L. S., R. P. Waldren and I. D. Teare. 1973. Rapid determination of free proline for water-stress studies. Plant Soil 39: 205-207.

de Freitas, S. T., K. A. Shackel and E. J. Mitcham. 2011. Abscisic acid triggers whole-plant and fruit-specific mechanisms to increase fruit calcium uptake and prevent blossom end rot development in tomato fruit. J. Exp. Bot. 62: 2645-2656.

Giuffrida, F., M. Martorrana and C. Leonardi. 2009. How sodium chloride concentration in the nutrient solution influences the mineral composition of tomato leaves and fruits. HortScience 44: 707-711.

Hayashi, M. 1976. Studies on the dormancy and germination of rice seed. IV. The location and identification of the inhibitors and auxin within dormant seed organs. Jpn. J. Trop. Agr. 19: 156-161 (In Japanese with English abstract).

Hayashi, M. 1979. Studies on the dormancy and germination of rice seed. VI. The chromatographic identification of a germination inhibitor in rice seed. Jpn. J. Trop. Agr. 23: 1-5 (In Japanese with English abstract).

Hidaka, K., M. Kitano, T. Wajima, D. Yasutake, A. F. F. Mohammad, Y. Sago, T. Matsuoka and K. Ishikawa. 2009. Effective application of the concentrated deep seawater to soil-less culture of high quality tomato. 3. Effects of shortterm application on water and nutrient uptake of root and leaf photosynthesis. Eco-Engineering 21: 27-35 (In Japanese with English abstract).

Ho, L. C. and P. J. White. 2005. A cellular hypothesis for the induction of blossom-end rot in tomato. Ann. Bot. 95: 571581.

Oliveira, A. B., C. F. H. Moura, E. Gomes-Filho, C. A. Marco, L. Urban and M. R. A. Miranda. 2013. The impact of organic farming on quality of tomatoes is associated to increased oxidative stress during fruit development. PLoS One 8: e56354.

Paungfoo-Lonhienne, C., J. Visser, T. G. A. Lonhienne and S. Schmidt. 2012. Past, present and future of organic nutrients. Plant Soil 359: 1-18.

Rady, M. M. 2012. A novel organo-mineral fertilizer can mitigate salinity stress effects for tomato production on reclaimed saline soil. South African J. Bot. 81: 8-14.

Saito, T., N. Fukuda and S. Nishimura. 2006. Effect of salinity treatment duration and planting density on size and sugar content of hydroponically grown tomato fruits. J. Japan. Soc. Hort. Sci. 75: 392-398.

Saito, T., C. Matsukura, Y. Ban, K. Shoji, M. Sugiyama, N. Fukuda and S. Nishimura. 2008. Salinity stress affects assimilate metabolism at the gene-expression level during fruit development and improves fruit quality in tomato (Solanum lycopersicum L.). J. Japan. Soc. Hort. Sci. 77: 61-68.

Saure, M. C. 2014. Why calcium deficiency is not the cause of blossom-end rot in tomato and pepper fruit - a reappraisal. Sci. Hortic. 174: 151-154.

Taylor, M. D. and S. J. Locascio. 2004. Blossom-end rot: a calcium deficiency. J. Plant Nutr. 27: 123-139.

Terabayashi, S., Y. Miyaoi, T. Takahata and T. Namiki. 1988. Calcium concentration in tomato fruits grown in water culture in 
relation to the incidence of blossom-end rot. Sci. Rep. Kyoto Pref. Univ. Agr. 40: 8-14 (In Japanese with English abstract).

Tuna, A. L., C. Kaya, A. Muhammad, H. Altunlu, I. Yokas and B. Yagmur. 2007. The effects of calcium sulphate on growth, membrane stability and nutrient uptake of tomato plants grown under salt stress. Environ. Exp. Bot. 59: 173-178.

Turhan, E., L. Karni, H. Aktas, G. Deventurero, D. C. Chang, A. Bar-Tal and B. Aloni. 2006. Apoplastic anti-oxidants in pepper (Capsicum annuum L.) fruit and their relationship to blossom-end rot. J. Hort. Sci. Biotech. 81: 661-667.

Yoshida, Y., N. Irie, T. D. Vinh, M. Ooyama, Y. Tanaka, K. Yasuba and T. Goto. 2014. Incidence of blossom-end rot in relation to the water-soluble calcium concentration in tomato fruit as affected by calcium nutrition and cropping season. J. Japan. Soc. Hort. Sci. 83: 282-289.

Yoshida, Y., A. Shingai, M. Ooyama, K. Murakami and T. Goto. 2013. Incidence of blossom-end rot in relation to watersoluble $\mathrm{Ca}$ concentration in tomato fruits as affected by $\mathrm{Ca}$ nutrition under root restriction. Sci. Rep. Fac. Agr. Okayama Univ. 102: 21-28 (In Japanese with English abstract).

Zushi, K., N. Matsuzoe, S. Yoshida and J. Chikushi. 2005. Comparison of chemical composition contents of tomato fruit grown under water and salinity stresses. J. SHITA 17: 128136 (In Japanese with English abstract). 